\title{
Thomas Paterson Morley (1920-2012)
}

Dr. Thomas Paterson Morley was born in 1920, the second of four children of Professor John Morley and Molly Simon of Manchester, England. His father was Professor of Surgery at the University of Manchester. In 1927, at age seven, as was customary in England, he was sent to boarding school at the Dragon School in Oxford, followed by the Rugby School in Rugby, Warwickshire. Soon after his arrival at boarding school, his beloved mother died from an infection, a loss that stayed with him throughout his life.

Morley went to Oxford for his BA degree in 1940, and his BM and $\mathrm{BCh}$ degrees in 1943 in medical school where he met his future wife, Helen Briggs, another medical student, in anatomy class. Tom and Helen were married in 1943, and honeymooned in England's Lake District. Shortly after their wedding, Morley spent six months as a house surgeon (intern) to Manchester's lead neurosurgeon, Professor Geoffrey Jefferson. His appointment with Jefferson was somewhat nepotic, as the Morley homestead in Manchester was close to the Jefferson's. Morley knocked on Jefferson's door, and asked for a job, whereupon Jefferson replied

"Nobody wants to come to my service, because it is too much like hard work, and I won't give you any time." Morley recalled these six months as being extremely difficult with many sleepless nights, and challenging cases. But it was this six month period which helped shape Morley's interests in a future career in neurosurgery.

In 1944, Morley joined the Royal Air Force (RAF) as a squadron medical office and was posted first in England, and then to Pune, India, north of Goa. After the war, he obtained his Royal College Fellowship in 1948 and then returned to Manchester to pursue his main interest, specialty training in neurosurgery, where he spent the next three and a half years with Jefferson.

Upon completion of his training in neurosurgery with Jefferson, Morley was in need of permanent employment. At the time, job opportunities for neurosurgeons in England were scarce. As fate would decree, Botterell, who met Jefferson during WWII, asked Jefferson to facilitate the recruitment of one of his trainees to Toronto where KG McKenzie and Botterell were in dire need of assistance. Accordingly, Botterell wrote to Morley and asked him if he would consider coming to Toronto to begin a career in neurosurgery. Morley was very pleased to receive this personal letter from Botterell, not realizing that nearly all of his colleagues in Manchester had received the same letter of invitation!

Morley jumped at the opportunity, and began a one year fellowship in neurosurgery at the Toronto General Hospital (TGH), living in the College Wing of the hospital, making daily ward rounds with the residents, William Horsey and William Lougheed, and assisting with the cases of Botterell and McKenzie before he was hired to the permanent staff in neurosurgery. In 1953, Helen and their two young daughters, Jane and Rosamund, emigrated to Canada to join Morley, and three years later, the couple's third child, David was born.

Over the next five years, Morley took a lot of night calls for Botterell, McKenzie and William Keith who was Head of Neurosurgery at the Toronto Western Hospital. His practice grew and he began specializing in brain tumour surgery and procedures used to treat trigeminal neuralgia. Morley quickly became a skillful technical neurosurgeon demonstrating complete economy of motion in the operating room and speeding his way through the most exacting and difficult procedures, to the great benefit of his patients.

As a clinical research niche, Morley moved forward with a project he had initially started with Jefferson in Manchester on the use of radioactive phosphorus $\left({ }^{32} \mathrm{P}\right)$ for the intracranial localization of brain tumours in patients. Another area of great research interest for Morley was in the use of echoencephalography where ultrasound was used to delineate the presence of midline shift of structures in the case of intracranial tumours or trauma.

As for basic science research work, Morley was encouraged by Botterell to visit the University of Texas at Galveston to learn about tissue culture of human brain tumours. In Galveston, Morley studied with CM Pomerat who was the only scientist studying in vitro models of brain tumours. "It was just like gardening. You plant something, and it grows!", said Morley. Botterell arranged for Morley to have a lab in the Neuropathology Laboratory at the Banting Institute on College Street. Before long, Morley started growing meningiomas, gliomas, and a few pituitary tumors. One of his seminal 
contributions to this field was his isolation of circulating glioma cells from the jugular vein from patients harbouring intracranial malignant gliomas.

In 1962, Morley succeeded Botterell as Head of the Division of Neurosurgery at TGH. Two years later, Morley was appointed as Chair of Neurosurgery. Morley expanded the residency program to two residents per year. He helped form the neurosurgery unit at the Wellesley Hospital in 1968 and recruited Ken Livingston to head that new Division. In 1974, the neurosurgery unit at Sunnybrook was established. In 1977 and 1979, he summarized the state of the neurosurgical training programs in Canada for the neurosurgical literature. There can be no question that the world wide reputation held by the Division of Neurosurgery in those years was directly attributable to Morley's enlightened stewardship.

Throughout his career, Morley held numerous leadership positions in medicine and neurosurgery including President of the Academy of Medicine of Toronto, President of the Canadian Neurosurgical Society, Vice President of the Society of Neurological Surgeons, and Vice President of the Neurosurgical Society of America.

One of Morley's greatest passions in academic neurosurgery was editing "Current Controversies in Neurological Surgery", a multi-authored book published by Saunders in 1976 in which he assembled opinion pieces from the leaders of neurosurgery around the globe, and provided commentary on their procedures or techniques. Current Controversies became the definitive and authoritative text of the specialty during those years, and Morley's international reputation grew accordingly.

In 1979, Morley stepped down as University Division Chair of Neurosurgery to be succeeded by Alan Hudson. Morley continued with his busy neurosurgical practice at the Toronto General Hospital until 1985 when he retired from the University. Towards the latter part of his professional career, and beyond, Morley became interested in writing about the history of neurosurgery in Canada, and wrote a scholarly article and the definitive book on the founder of Neurosurgery in Canada, KG McKenzie. Morley became the General Editor of the 24 volume Canadian Medial Lives series which included biographies of such Canadian medical luminaries as William Mustard, Alan Brown, and Duncan Graham.

A total of 50 residents finished either all or a significant part of their training under Morley. All residents who rotated on the neurosurgical service at TGH with Morley remember the tradition of tea at $4 \mathrm{pm}$ during rounds. There are also distinct memories of Morley running up the stairs, all twelve floors, of the Urquhart wing, and of course expecting the residents to do the same. When the residents who lagged far behind reached the top, puffing all the while, he would chide them to get into shape. It did not matter that most of the residents had been up all night!

In his name and honour, and for his early devotion to basic science research in neurosurgery, the Morley Prize was created in the Division of Neurosurgery in 1986 to recognize the neurosurgery resident who has presented the best research paper each year.

Morley will be remembered for his encouraging words to the residents in his formal British accent, his self-deprecating ways, his charm, and his incredible wit, albeit sometimes quirky. In completing his earthly journey, Morley leaves his wife Helen, children David, Rosamund, Jane and Luke, eight grandchildren, and two great-grandchildren. It is only right and fitting that we pay tribute here to another great Canadian medical life and neurosurgeon who has had a profound impact on the art and practice of neurosurgery in this country.

Fred Gentili, James T. Rutka University of Toronto, Toronto, Ontario

\section{ACKNOWLEDGEMENT}

The authors thank David and Jane Morley for their review of the family events in this tribute, and Daniel Rutka for transcribing the interviews from videotape footage taken of Dr. Morley in 2004. 